\title{
Mapping the Photochemistry of European Mid-Latitudes Rivers: An Assessment of Their Ability to Photodegrade Contaminants
}

\author{
Luca Carena and Davide Vione *(i) \\ Dipartimento di Chimica, Università di Torino, Via Pietro Giuria 5, 10125 Torino, Italy; luca.carena@unito.it \\ * Correspondence: davide.vione@unito.it; Tel.: +39-011-6705296
}

Academic Editor: Barbara Bonelli

check for

Received: 19 December 2019; Accepted: 14 January 2020; Published: 20 January 2020

updates

\begin{abstract}
The abiotic photochemical reactions that take place naturally in sunlit surface waters can degrade many contaminants that pose concern to water bodies for their potentially toxic and long-term effects. This works aims at assessing the ability of European rivers to photoproduce reactive transient intermediates, such as $\mathrm{HO}^{\bullet}$ radicals and the excited triplet states of chromophoric dissolved organic matter $\left({ }^{3} \mathrm{CDOM}^{*}\right)$, involved in pollutant degradation. A photochemical mapping of the steady-state concentrations of these transients was carried out by means of a suitable modeling tool, in the latitude belt between 40 and $50^{\circ} \mathrm{N}$. Such a map allowed for the prediction of the photochemical lifetimes of the phenylurea herbicide isoproturon (mostly undergoing photodegradation upon reaction with $\mathrm{HO}^{\bullet}$ and especially ${ }^{3} \mathrm{CDOM}^{*}$ ) across different European countries. For some rivers, a more extensive dataset was available spanning the years 1990-2002, which allowed for the computation of the steady-state concentration of the carbonate radicals $\left(\mathrm{CO}_{3}{ }^{\bullet-}\right)$. With these data, it was possible to assess the time trends of the photochemical half-lives of further contaminants (atrazine, ibuprofen, carbamazepine, and clofibric acid). The calculated lifetimes were in the range of days to weeks, which might or might not allow for efficient depollution depending on the river-water flow velocity.
\end{abstract}

Keywords: Indirect photochemistry; hydroxyl radicals; direct photolysis; photochemical modeling; dissolved organic matter; CDOM

\section{Introduction}

During the last three decades, the presence of emerging contaminants has been widely detected in surface and groundwaters around the world [1-4], posing a high environmental concern because of the adverse effects of these compounds on both aquatic organisms and human beings [5,6]. The so-called contaminants of emerging concern derive from anthropogenic activities; they include pharmaceuticals and personal-care products (PPCPs), pesticides, as well as nanoparticles. There are several ways by which the emerging contaminants (ECs) reach surface waters, including rivers, lakes, and the ocean, depending upon each compound and its use. For instance, PPCPs inputs to water bodies mainly derive from wastewater treatment plants (WWTPs), which are not able to completely degrade the received pollutant load [7]. In contrast, pesticides reach watercourses through soil runoff [8,9] and contamination of groundwater [10], which is an important water supply for rivers and lakes.

Although the persistence of both traditional pollutants and ECs is a huge problem for aquatic systems [11], sunlit water bodies can naturally trigger abiotic photochemical reactions that degrade dissolved compounds [12,13]. Indeed, pollutants can be degraded by reactive transients, called Photochemically Produced Reactive Intermediates (PPRIs), which are generated by the irradiation of chemical species that naturally occur in water bodies. The main PPRIs are hydroxyl and carbonate radicals $\left(\mathrm{HO}^{\bullet}\right.$ and $\mathrm{CO}_{3}{ }^{\bullet-}$, respectively), singlet oxygen $\left({ }^{1} \mathrm{O}_{2}\right)$, and the excited triplet states of 
chromophoric dissolved organic matter $\left({ }^{3} \mathrm{CDOM}^{*}\right)$. CDOM is the main photosensitizer forming PPRIs in surface waters, followed by nitrate and nitrite. In particular, CDOM produces directly ${ }^{3} \mathrm{CDOM}^{*}$ and $\mathrm{HO}^{\bullet}$ (although the exact pathway(s) to the latter species are not yet fully elucidated). Then, ${ }^{3} \mathrm{CDOM}^{*}$ react with dissolved oxygen (their main sink) to produce ${ }^{1} \mathrm{O}_{2}$, and with $\mathrm{CO}_{3}{ }^{2-}$ to yield $\mathrm{CO}_{3}{ }^{-}{ }^{-}$. At the same time, $\mathrm{HO}^{\bullet}$ radicals oxidize $\mathrm{HCO}_{3}{ }^{-} / \mathrm{CO}_{3}{ }^{2-}$ to $\mathrm{CO}_{3}{ }^{\bullet-}$. Nitrate and nitrite directly produce $\mathrm{HO}$ radicals and then $\mathrm{CO}_{3}{ }^{--}$as a consequence of the reactions between $\mathrm{HCO}_{3}{ }^{-} / \mathrm{CO}_{3}{ }^{2-}$ and $\mathrm{HO}^{\bullet}$ [14]. Water components can also inhibit the phototransformation processes. For instance, dissolved organic matter (DOM) scavenges both $\mathrm{HO}^{\bullet}$ and $\mathrm{CO}_{3}{ }^{\bullet}$, and it can also inhibit the ${ }^{3} \mathrm{CDOM}^{*}$-induced degradation of pollutants by back-reducing their partially oxidized reaction intermediates, thanks to its antioxidant moieties $[15,16]$. Besides indirect photochemistry through PPRI reactions, direct photolysis (i.e., direct transformation upon sunlight absorption) plays an important role in the whole degradation pathways of contaminants $[17,18]$. In general, all these reactions act as self-depollution processes for water bodies. However, they can sometimes induce the formation of compounds that are more harmful than the parent molecule $[19,20]$. Finally, it must be pointed out that biodegradation [21] and, to a lesser extent, chemical hydrolysis [22] are other efficient degradation processes for water pollutants [23].

Many works have been carried out to measure both the production of PPRIs, and their ability to degrade pollutants during lab experiments (see, e.g., in [24-26]). Unfortunately, the complexity of the aquatic environment does not easily allow for direct measurements in the field. As an alternative, by means of modeling tools one can calculate PPRIs formation and scavenging as well as pollutant photodegradation processes. The models take into account several environmental parameters; the exact reproduction of which would require a lot of efforts and time in laboratory experiments.

This modeling work deals with the assessment of the formation potential of the main PPRIs in European rivers, located in the mid-latitude belt between 40 and $50^{\circ} \mathrm{N}$. The PPRIs steady-state concentrations were calculated and mapped over the relevant region, based on water chemistry data that are available in the GEMStat database [27]. This allowed us to assess how much these watercourses would be able to photodegrade water pollutants, such as isoproturon, carbamazepine, ibuprofen, atrazine, and clofibric acid, which have been widely detected in both surface and groundwater [28-33]. Some pollutants can even produce more toxic compounds by photodegradation, as in the case of carbamazepine and clofibric acid [34,35]. The approach to photochemical modeling used here has been previously validated, and shown to be able to predict the photochemical reactivity of the investigated compounds in surface-water bodies [36-39]. Indeed, for several aquatic environments we have found a good agreement between the modeled photochemical half-lives of ibuprofen, carbamazepine, atrazine, and clofibric acid, which are an indication of the persistence of these pollutants in a water body, and the lifetimes actually measured in the field (Table 1).

Table 1. Literature comparisons between the modeled and the field-measured photochemical half-life times of some of the contaminants investigated in the present work.

\begin{tabular}{cccccc}
\hline \multirow{2}{*}{ Compound } & \multicolumn{2}{c}{ Photochemical Half-Life Time, Days } & & Location & \multirow{2}{*}{ Ref. } \\
\cline { 2 - 3 } & Model & Field & & & \\
\hline Ibuprofen & $60 \pm 10$ & $60-115$ & & Lake Greifensee & {$[36]$} \\
Carbamazepine & $110 \pm 45$ & $140 \pm 50$ & & Lake Greifensee & {$[37]$} \\
\hline \multirow{2}{*}{ Atrazine } & $17 \pm 4$ & $20-21$ & & Chesapeake Bay (1 m depth) & {$[38]$} \\
& $64 \pm 18$ & $67-100$ & Chesapeake Bay (10 m depth) & \\
\hline Clofibric acid & $60-120$ & 70 & & Lake Greifensee & {$[39]$} \\
\hline
\end{tabular}




\section{Results and Discussion}

\subsection{Mapping the PPRIs Steady-State Concentrations}

The steady-state concentrations of ${ }^{3} \mathrm{CDOM}^{*}$ and $\mathrm{HO}^{\bullet}$ radicals, referred to late spring/early summer fair-weather conditions, are here reported as average values for the period 1990-1995 (see the "Material and Methods" section for further details). The singlet oxygen $\left({ }^{1} \mathrm{O}_{2}\right)$ map is not shown here because it closely mirrors that of ${ }^{3} \mathrm{CDOM}^{*}[40]$. The ${ }^{3} \mathrm{CDOM}^{*}$ map is reported in Figure 1 , showing that ${ }^{3} \mathrm{CDOM}^{*}$ ranges between $\sim 6.0 \times 10^{-17}$ and $\sim 9.0 \times 10^{-16} \mathrm{~mol} \mathrm{~L}^{-1}$. These are reasonable concentration values for ${ }^{3} \mathrm{CDOM}^{*}$, which are often measured during the irradiation of both synthetic and environmental DOM solutions [25,41]. Because both the water optical depth $(0.1 \mathrm{~m})$ and the DOM photochemical features were kept constant during modeling, the higher is the content of dissolved organic carbon (DOC, which is a measure of DOM, see Figure S1 in the Supplementary Materials), the higher is the steady-state concentration of ${ }^{3} \mathrm{CDOM}^{*}$.

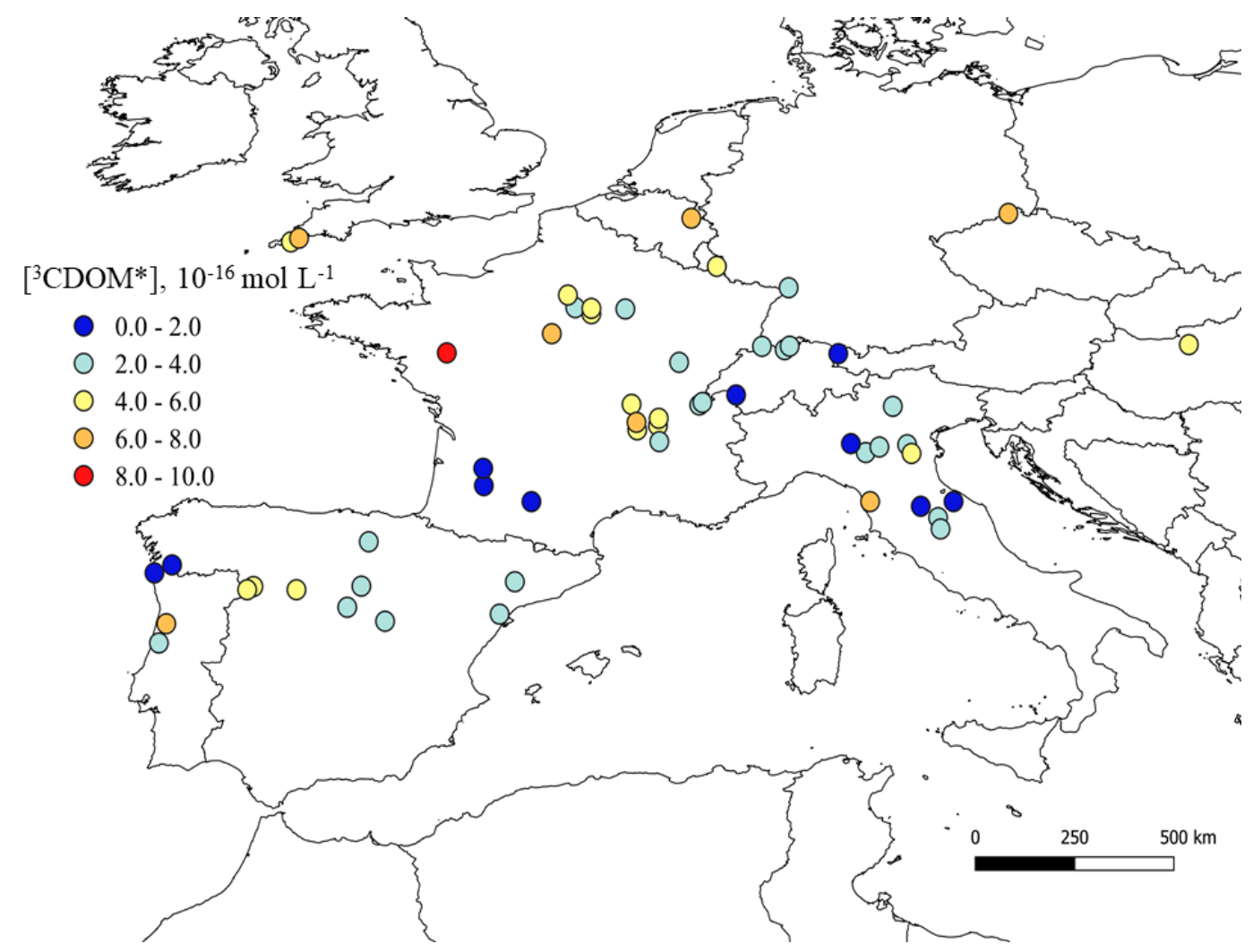

Figure 1. ${ }^{3} \mathrm{CDOM}^{*}$ map of European rivers located in the latitude belt from 40 to $50^{\circ} \mathrm{N}$. Data refer to the month of June and are average values over the period 1990 to 1995 . The map was made by means of the QGIS software (version 3.2.2 ‘Bonn' [42]).

The steady-state concentrations of $\mathrm{HO}^{\bullet}$ radicals are shown in Figure 2, and they deserve further explanation. Because (C)DOM is both the main scavenger, and (often) the main photochemical source of $\mathrm{HO}^{\bullet}$ radicals, the DOC datum alone might theoretically be used to roughly assess the $\mathrm{HO}^{\bullet}$ steady-state concentration $\left(\left[\mathrm{HO}^{\bullet}\right]\right)$. This modeling approach was here adopted as first approximation for those stations, for which the concentration values of the other $\mathrm{HO}^{\bullet}$ sources and sinks (i.e., $\mathrm{NO}_{3}{ }^{-}, \mathrm{NO}_{2}{ }^{-}$, $\mathrm{HCO}_{3}{ }^{-}$, and $\mathrm{CO}_{3}{ }^{2-}$ ) were not available. Actually, because the role of $\mathrm{NO}_{3}{ }^{-}$and $\mathrm{NO}_{2}{ }^{-}$as $\mathrm{HO}^{\bullet}$ sources is higher than the role of $\mathrm{HCO}_{3}{ }^{-}, \mathrm{CO}_{3}{ }^{2-}$, and $\mathrm{NO}_{2}{ }^{-}$as $\mathrm{HO}^{\bullet}$ scavengers [43-46], by using a DOC-only approach one gets a lower limit for the steady-state [ $\left.\mathrm{HO}^{\bullet}\right]$ (see Figure $\mathrm{S} 2$ for a quantitative assessment of the differences, which are expected to occur in reasonable environmental scenarios). 


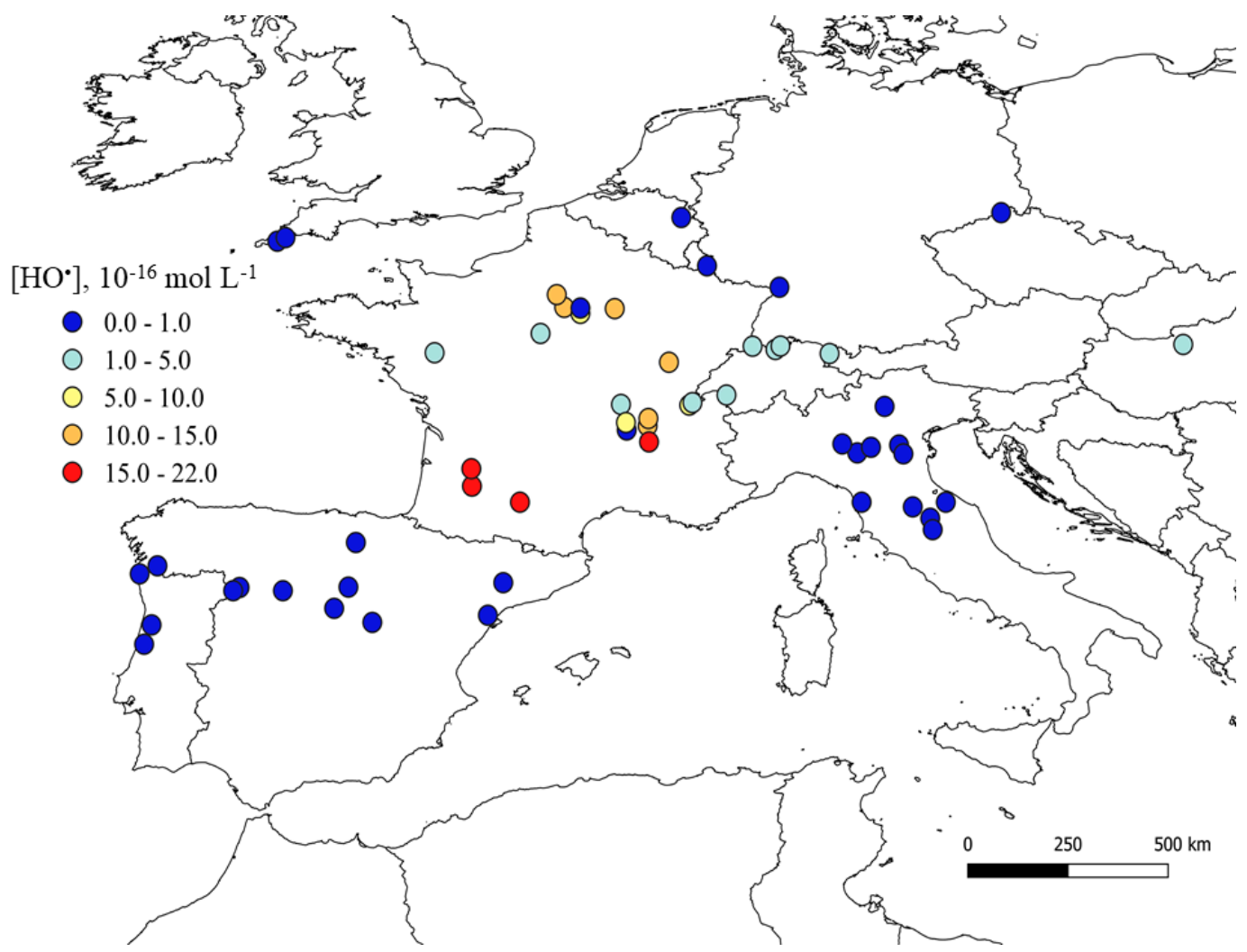

Figure 2. $\mathrm{HO}^{\bullet}$ radicals maps of European rivers located in the latitude belt from 40 to $50^{\circ} \mathrm{N}$. Data refer to the month of June and are average values over the period 1990-1995. The maps were made by means of the QGIS software (version 3.2.2 'Bonn' [42]). Note that, apart from France and Switzerland, the other calculated $\left[\mathrm{HO}^{\bullet}\right]$ values should be considered as lower limits.

Sufficiently complete datasets were available for France and Switzerland (see Figure S3 for the $\mathrm{NO}_{3}{ }^{-}$maps), for which consideration of all the main $\mathrm{HO}^{\bullet}$ sources and sinks provided more realistic $\left[\mathrm{HO}^{\bullet}\right]$ levels. Therefore, the main reason for the difference in the calculated $\left[\mathrm{HO}^{\bullet}\right]$ between these two countries and the others is the availability of a more complete set of water chemistry data for the former. This issue needs consideration when the calculated lifetimes of pollutants are compared.

The data pertaining to six Swiss monitoring stations were characterized by the most complete dataset, which allowed for an extension of the investigated period over a dozen years (i.e., from 1990 to 2002), and for the calculation of the steady-state $\left[\mathrm{CO}_{3}{ }^{--}\right]$as well. Figure 3 a shows the time trends of the steady-state concentrations of $\mathrm{HO}^{\bullet},{ }^{3} \mathrm{CDOM}^{*}$, and $\mathrm{CO}_{3}{ }^{\bullet-}$ in Swiss rivers between 1990 and 2002. The reported results are values averaged among all the available watercourses, for the month of June of each year, and the associated standard deviations account for the geographical variability of the PPRIs concentrations.

As average values over all the Swiss stations, the steady-state $\left[\mathrm{HO}^{\bullet}\right]$ and $\left[{ }^{3} \mathrm{CDOM}^{*}\right]$ did not undergo significant variations from 1990 to 2002. There were exceptions for the single stations, however, and particularly for Rekingen (Rhine river) and Port du Scex (Rhône river), which showed a statistically significant decrease of HO• (Rekingen: $\mathrm{r}=-0.85, p=9.2 \times 10^{-4}$; Port du Scex: $\mathrm{r}=-0.66, p=0.03$ ) and an increase of ${ }^{3} \mathrm{CDOM}^{*}$ (Rekingen: $\mathrm{r}=0.73, p=0.01$ ).

In the case of the steady-state $\left[\mathrm{CO}_{3}{ }^{-}\right]$, one observes an overall two-fold decrease of the values as all-station averages from 1990 to 2002 (Figure 3a). This substantial decrease would be the consequence of two parallel variations, namely a decrease of nitrate (indirect $\mathrm{CO}_{3}{ }^{\bullet-}$ source via $\mathrm{HO}{ }^{\bullet}$ photogeneration) and an increase of the DOC (direct $\mathrm{CO}_{3}{ }^{--}$sink [46]). 


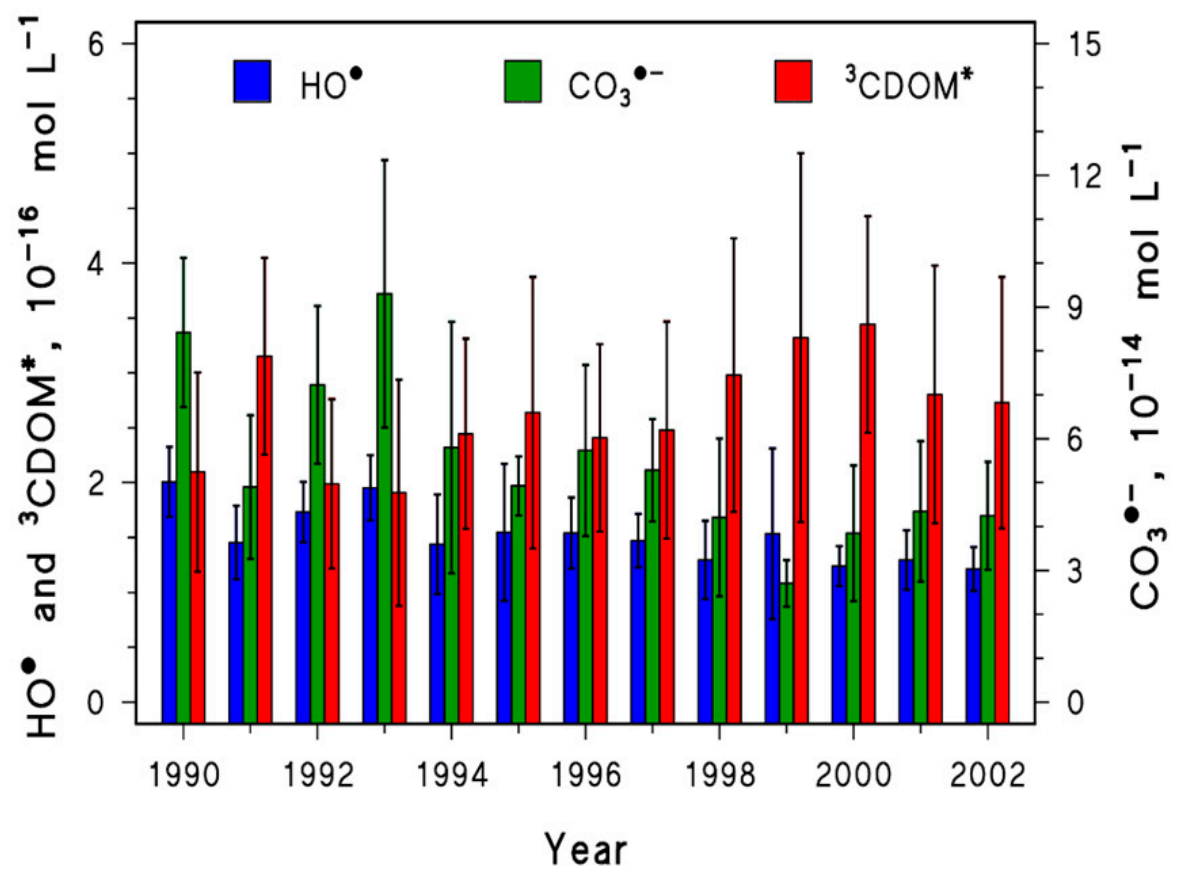

(a)

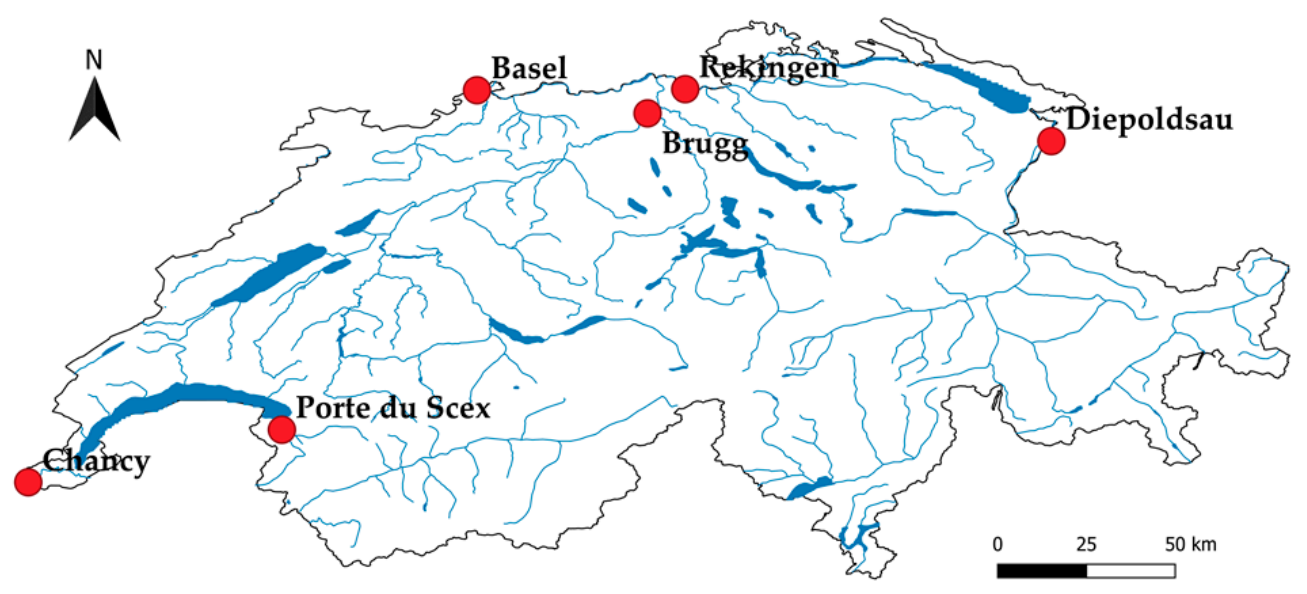

(b)

Figure 3. (a) PPRIs steady-state concentration trends for Swiss rivers during the month of June 1990-2002. The relevant input data for modeling the PPRIs concentrations were (C)DOM, $\mathrm{NO}_{3}{ }^{-}$, $\mathrm{HCO}_{3}{ }^{-}$and $\mathrm{CO}_{3}{ }^{2-}$, plus $0.1 \mathrm{~m}$ as the water optical depth. Error bars are standard deviations accounting for the spatial variability among the different stations, shown in panel (b).

The overall trend observed in Swiss rivers suggests an approximately constant behavior towards the photoinduced processes triggered by $\mathrm{HO}^{*}$ and ${ }^{3} \mathrm{CDOM}^{*}$, but an important loss in the ability to carry out photodegradation by $\mathrm{CO}_{3}{ }^{-}$. The latter issue can have an impact over the photochemical lifetimes of the compounds that are mainly (or otherwise considerably) degraded by $\mathrm{CO}_{3}{ }^{\bullet-}$, such as electron-rich phenols, anilines, and sulfur-containing molecules [47]. 


\subsection{Modeling the Photodegradation of Contaminants}

The Europe-wide maps reported in Figures 1 and 2 can be used to get insight into the photodegradation kinetics of contaminants that mainly react with $\mathrm{HO}^{\bullet}$ and ${ }^{3} \mathrm{CDOM}^{*}$. However, just because of data-set differences, the $\left[\mathrm{HO}^{\bullet}\right]$ map provides higher values for France and Switzerland while underestimating the levels in the other investigated European countries. To minimize this bias, one should consider a model compound that mainly undergoes degradation by ${ }^{3} \mathrm{CDOM}^{*}$. Phenylurea herbicides belong to this category [48] and, in particular, isoproturon (IPT) is a compound that has a second-order reaction rate constant with ${ }^{3} \mathrm{CDOM}^{*}$ that is not so far from that with $\mathrm{HO}^{\bullet}$ $\left(k_{I P T+H O}=7.9 \times 10^{9} \mathrm{~L} \mathrm{~mol}^{-1} \mathrm{~s}^{-1}, k_{I P T+{ }^{3} C D O M *}=3.2 \times 10^{9} \mathrm{~L} \mathrm{~mol}^{-1} \mathrm{~s}^{-1}\right)$, while also undergoing limited directphotolysis $[49,50]$. IPT is typically used in cereals and undergoes runoff processes when applied to the crops [51-53], making it a potential water contaminant. For this reason, IPT has been detected in several rivers during the 1990s [54-56], and it is often detected around Europe nowadays as well [57-59]. IPT is moderately toxic toward aquatic organisms, showing both additive and synergistic toxic effects with other pesticides [60,61].

The European map of IPT half-life times is reported in Figure 4 . It appears that IPT photodegradation would be faster in Central Europe, with photochemical half-lives of less than one month, because of higher $\left[{ }^{3} \mathrm{CDOM}^{*}\right]$ values. In particular, in France and Switzerland, the half-life time would be in the range of a few days to two weeks. The case of the rivers located in SW France is quite interesting, because relatively fast IPT degradation is foreseen there despite the low $\left[{ }^{3} \mathrm{CDOM}^{*}\right]$ values shown in Figure 1. The reason is that the same locations showed very high [HO`] levels (see Figure 2), which could offset the limited role of ${ }^{3} \mathrm{CDOM}^{*}$. Elevated $\mathrm{HO}^{\bullet}$ values would be found in those stations because of the combination of moderately high nitrate concentration with quite low DOC, which enhances $\mathrm{HO}^{\bullet}$ photogeneration while minimizing its scavenging.

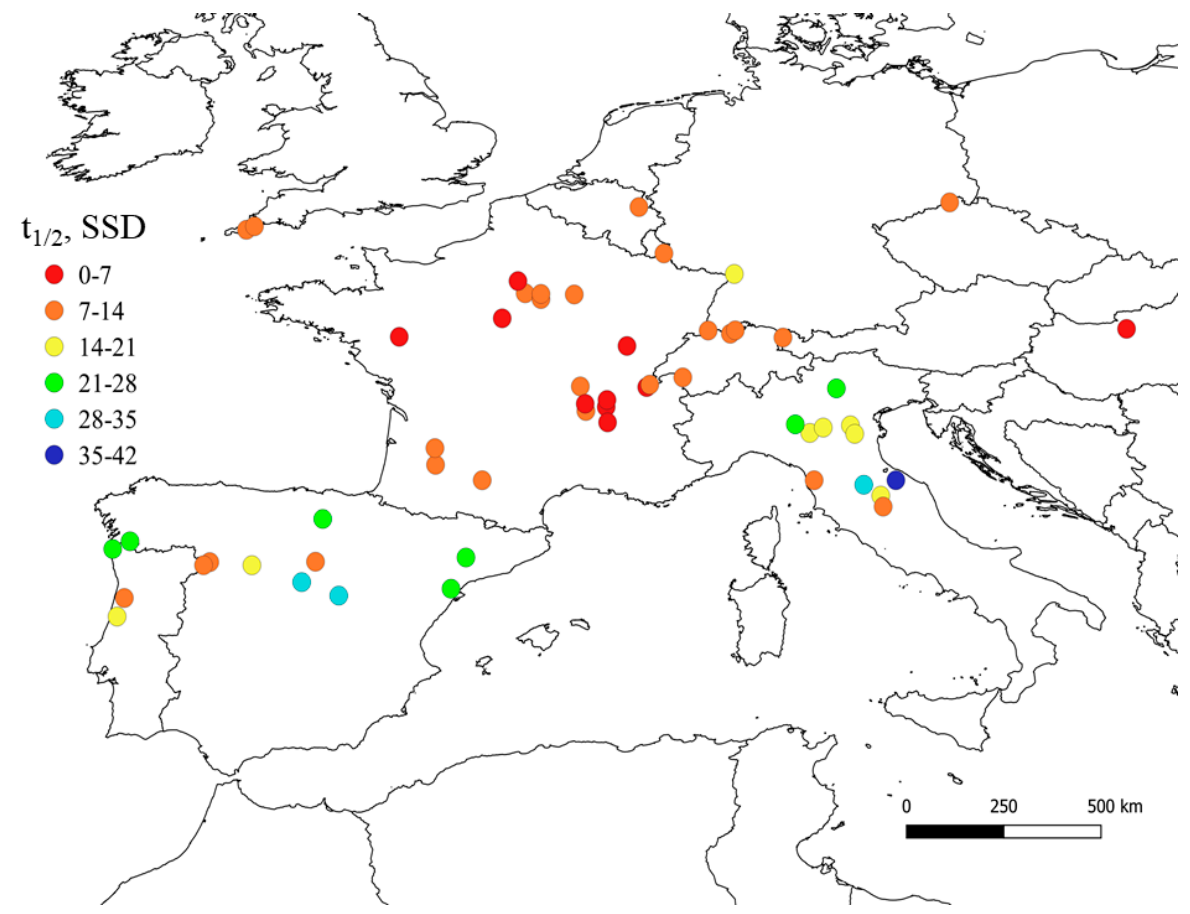

Figure 4. Map of IPT photochemical half-life times $\left(t_{1 / 2}\right)$ for European rivers located in the latitude belt from 40 to $50^{\circ} \mathrm{N}$. Data refer to the month of June (SSD = sunny summer days) and are average values over the period 1990-1995. The relevant input data for modeling $t_{1 / 2}$ were from Figure $1\left({ }^{3} \mathrm{CDOM}^{*}\right)$ and Figure $2\left(\mathrm{HO}^{\bullet}\right.$ radicals), and the lifetime was calculated as $t_{1 / 2}=\ln 2\left(k_{I P T+H O}\left[H^{\bullet}\right]+k_{I P T+{ }^{3} C D O M *}\left[{ }^{3} C D O M *\right]\right)^{-1}$. The maps were made by means of the QGIS software (version 3.2.2 'Bonn'; [42]). 
It is also interesting to assess the photodegradation kinetics of different pollutants over a longer time interval, to see to what extent variations in photochemistry can affect the self-depollution ability of rivers. As already mentioned in Section 2.1., this assessment was possible in the case of Swiss rivers for the period 1990-2002. Moreover, the Swiss dataset was complete enough to allow for the calculation of the degradation kinetics of clofibric acid (hereinafter CLO), ibuprofen (IBP), atrazine (ATZ), and carbamazepine (CBZ). The main involved photodegradation pathways are $\mathrm{HO}^{\bullet}$ and ${ }^{3} \mathrm{CDOM}^{*}(\mathrm{CLO})$, $\mathrm{HO}^{\bullet}$ and direct photolysis (IBP), mostly $\mathrm{HO}^{\bullet}(\mathrm{CBZ})$, as well as $\mathrm{HO}^{\bullet}, \mathrm{CO}_{3}^{\bullet-}$ and ${ }^{3} \mathrm{CDOM}^{*}$ with comparable weight (ATZ) (see Figure S4a).

On average over all the Swiss stations, the photodegradation kinetics of CLO, IBP, and CBZ would not change much (see Figure 5). This result reflects the limited overall variability in the steady-state $\left[\mathrm{HO}^{\bullet}\right]$ and $\left[{ }^{3} \mathrm{CDOM}^{*}\right]$ that was reported in Figure $3 \mathrm{a}$. The scenario is slightly different in the case of ATZ, with somewhat longer half-lives in the period 1994-2002 compared to 1990-1993. This finding is a consequence of the fact that the ATZ half-life showed a statistically significantly increase over time in five out of the six stations, the only exception being Chancy (located along the Rhone river, see Figure 3b). Actually, among the considered contaminants, ATZ is the only one undergoing important photodegradation by reaction with $\mathrm{CO}_{3}{ }^{\bullet-}$, and this transient species is expected to decline over the investigated time period (see Figure 3a).

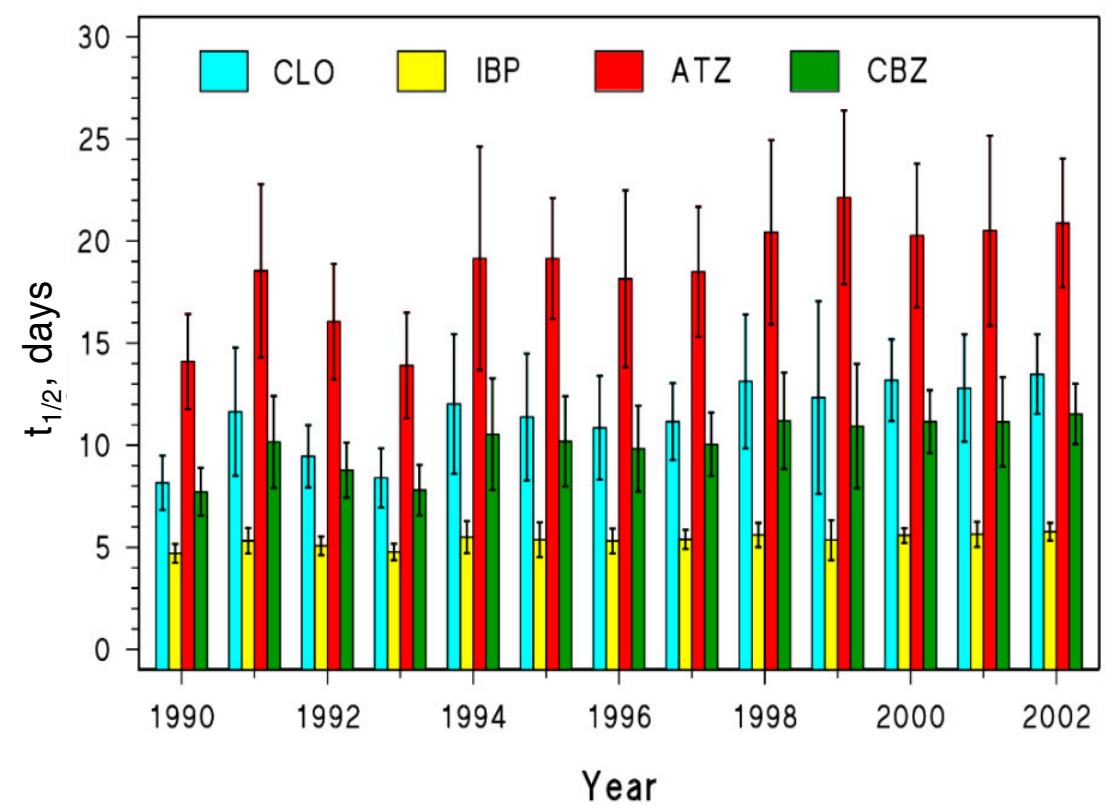

Figure 5. Photochemical half-life time $\left(\mathrm{t}_{1 / 2}\right)$ trends for CLO, IBP, ATZ and CBZ in Swiss rivers $(0.1 \mathrm{~m}$ as optical water depth) during the month of June for 1990-2002. Error bars are standard deviations accounting for the spatial variability of the model results.

Even for those contaminants, for which the overall photodegradation kinetics did not change much over time as an all-station average, there were some important differences as far as the single sites are concerned. As already mentioned in Section 2.1., the calculated steady-state [ $\left.\mathrm{HO}^{\bullet}\right] \mathrm{had}^{\mathrm{a}}$ significant decline in the Swiss stations of Rekingen and Port du Scex. This trend is reflected into a statistically significant increase of the lifetimes of CLO (Rekingen: $\mathrm{r}=0.83, p=4.1 \times 10^{-4}$; Port du Scex: $\mathrm{r}=0.67, p=0.01$ ), IBP (Rekingen: $\mathrm{r}=0.81, p=7.3 \times 10^{-4}$; Port du Scex: $\mathrm{r}=0.67, p=0.01$ ) and CBZ (Rekingen: $\mathrm{r}=0.83, p=3.9 \times 10^{-4}$; Port du Scex: $\mathrm{r}=0.68, p=0.01$ ). In the case of CBZ, a statistically significant lifetime increase was also assessed in the station of Brugg $(r=0.66, p=0.03)$, because of the parallel decrease of both $\left[\mathrm{HO}^{\bullet}\right]$ and $\left[\mathrm{CO}_{3}^{\bullet-}\right]$.

In the case of $\mathrm{CBZ}$, we were also able to calculate the formation yield of acridine, which is a mutagenic transformation intermediate formed from CBZ upon direct photolysis and $\mathrm{HO}^{\bullet}$ 
reaction [34,37]. The acridine formation yield was calculated as the ratio between the formation rate constant of acridine and the transformation rate constant of CBZ [62]. The acridine yield did not change much over time, and it was always $\sim 2.5 \%$ with limited variability among the different stations (Figure S4c). Although not exceedingly high, this formation yield of a mutagenic compound would pose some concern. As mentioned before, the photodegradation kinetics of CBZ would slow down over time in some stations and, at constant yield, the formation rate constant of acridine is predicted to undergo a parallel decrease. In those cases, the loss in performance towards self-depuration would be offset by a correspondingly lower potential to produce a harmful transformation intermediate.

The lifetimes reported in Figure 5 show some long-term trends and reflect the variability among stations, but they range overall between 5 and 25 days. The lowest photochemical persistence is predicted for IBP, and the highest for ATZ. When considering a water flow velocity of $1 \mathrm{~m} \mathrm{~s}^{-1}$ [63,64], these lifetimes would translate into river half-life lengths ranging between around 400 and over $2000 \mathrm{~km}$. These are the river lengths that would be required for the pollutants to halve their concentration due to photochemical depollution [65], and they mean that photodegradation would be hardly complete when river water leaves Switzerland. The scenario would become quite different under water-scarcity conditions, when the water flow velocity can decrease down to $0.1 \mathrm{~m} \mathrm{~s}^{-1}$ [66]. In this case, with half-life river lengths ranging between 40 and $200 \mathrm{~km}$, river water photodegradation of contaminants would become much more important. This finding confirms earlier assumptions, according to which photochemistry could be an important self-depollution process in rivers under drought conditions, in which case photodegradation may help cope with the increased pollution caused by lower dilution of, e.g., wastewater discharges [65].

\section{Materials and Methods}

The investigation area comprised European rivers located in the latitude belt between 40 and $50^{\circ} \mathrm{N}$ (Table S1). The PPRIs steady-state concentrations were calculated for these water bodies in the month of June, when the highest photoactivity of surface waters should occur. For calculations, we used photochemistry-modeling software derived from the Aqueous Photochemistry of Environmentally-occurring Xenobiotics (APEX) code [62]. Although the software version we used here is not yet available for public use, it has already been employed by us for similar modeling purposes in recently published work [67].

Solar spectral irradiance, optical water depth, and photosensitizer concentrations were the main input data for computation. The sun spectrum reaching the Earth surface in June at $45^{\circ} \mathrm{N}$ during clear-sky conditions was used [68], as it is reasonably representative of the considered latitude belt. Despite some differences between the spectral irradiance at $40^{\circ} \mathrm{N}$ and at $50^{\circ} \mathrm{N}$ (Figure S5), variations above $310 \mathrm{~nm}$ are within the uncertainty of the photochemical model $(<20 \%)$ and the spectra can be considered very similar. Modeling was performed with $0.1 \mathrm{~m}$ as the water optical depth $(d)$, which allowed for a normalization of the computations without the need of taking into account unavailable seasonal hydrology variations in rivers, under different weather conditions.

Concentration data of the relevant photosensitizers (CDOM, nitrate, and nitrite) were obtained from the Global Environment Monitoring System website [27]. This website reports a wide dataset of water quality parameters around the globe. Suitable data allowing for photochemical modeling were practically available for Europe only, and they date back to the 1990s. We used the dissolved organic carbon (DOC) to quantify both DOM and CDOM, the latter assessed as the water absorption spectrum, on the basis of literature-reported correlations for inland surface waters [62]. The DOC data were not available for all the monitoring stations, because some stations reported instead the chemical oxygen demand (COD). Fortunately, in the case of surface waters the values of DOC and COD are correlated. To have a reasonably wide investigated area/period, we used the equation $D O C=$ 0.18.COD to assess the DOC when it was not available [69]. This correlation has already been used in previous work to model the photochemistry of Lake Peipsi (Estonia) [70]. The DOC maps are reported in the Supplementary Material (Figure S1). With the DOC datum it was possible to compute the PPRIs 
formation rates from sunlit CDOM, as well as their scavenging by DOM. The main assumption here was to consider a uniform, average behavior of (C)DOM as both PPRIs photosensitizer and scavenger. Indeed, although the (C)DOM type depends upon its source and the transformation processes it has undergone [71], variation of the (C)DOM photochemical properties could be less important than the natural environmental variability might suggest [72]. When available, nitrate (Figure S3) and nitrite concentrations data were used to compute $\mathrm{HO}^{\bullet}$ and $\mathrm{CO}_{3}{ }^{\bullet-}$ radical photochemistry. The calculation of the $\mathrm{CO}_{3}{ }^{\bullet-}$ steady-state concentration also required knowledge of the levels of $\mathrm{HCO}_{3}{ }^{-}$and $\mathrm{CO}_{3}{ }^{2-}$, because these anions are the main precursors of $\mathrm{CO}_{3}{ }^{\bullet-}$ when oxidized by $\mathrm{HO}^{\bullet}$ and ${ }^{3} \mathrm{CDOM}^{*}$ [45]. In particular, alkalinity and $\mathrm{pH}$ data from GEMStat were used to calculate $\left[\mathrm{HCO}_{3}{ }^{-}\right]$and $\left[\mathrm{CO}_{3}{ }^{2-}\right]$, with an iterative computation procedure explained in detail elsewhere [67]. Finally, we used input data included in the period between 1990 and 1995, where the dataset was most complete throughout Europe. In general, only those stations with DOC data for at least four years in this period were considered for modeling.

The photodegradation of isoproturon (IPT), clofibric acid (CLO), ibuprofen (IBP), atrazine (ATZ), and carbamazepine (CBZ) was assessed by calculating their half-life times $\left(t_{1 / 2}\right)$ as $t_{1 / 2}=\ln 2\left(k^{\prime}\right)^{-1}$. Here, $k^{\prime}$ (Equation (1)) is the pseudo-first order degradation rate constant of the considered contaminant $C$, accounted for by both direct photolysis and indirect photochemistry:

$$
k^{\prime}=\sum_{i}\left([i] \cdot k_{i+C}\right)+\Phi_{C} \sum_{j}\left[\Delta \lambda_{j} p_{\lambda_{j}}^{o} A_{\lambda_{j}, C}\left(1-10^{-A_{\lambda_{j}, \mathrm{CDOM}}}\right)\left(A_{\lambda_{j}, \mathrm{CDOM}}\right)^{-1}\right]
$$

In Equation (1), $k_{i+C}$ is the second-order rate constant for the reaction between the contaminant and the transient (PPRI) $i\left(i=\mathrm{HO}^{\bullet}, \mathrm{CO}_{3}^{\bullet-},{ }^{3} \mathrm{CDOM}^{*}\right) ; \Phi_{\mathrm{C}}$ is the direct photolysis quantum yield of the contaminant (see Table 2 for the relevant values); [ $i$ is the steady-state concentration of the PPRI; and $A_{\lambda_{j}, C}$ and $A_{\lambda_{j}, C D O M}$ are the spectral absorbances of, respectively, the contaminant and CDOM at the relevant wavelengths. The light-absorption calculations were based on the Bouguer-Beer-Lambert Law. In particular, $A_{\lambda_{j}, C D O M}$ was computed with the relationship $A_{\lambda_{j}, C D O M}=0.45 d D O C e^{-0.015 \lambda_{j}}$, which gives a suitable absorption spectrum for surface freshwaters [62]. Finally, $p_{\lambda_{j}}^{o}$ is the average solar spectral photon flux density reaching the Earth surface at $45^{\circ} \mathrm{N}$ during a fair-weather day in June. The sum in Equation (1) was calculated for increments $\Delta \lambda_{j}=1 \mathrm{~nm}$.

Table 2. Photoreactivity parameters used to assess the photochemical half-life times of the relevant contaminants. Note that the investigated compounds undergo negligible degradation by ${ }^{1} \mathrm{O}_{2}$.

\begin{tabular}{|c|c|c|c|c|}
\hline \multirow{2}{*}{ Contaminant } & \multicolumn{2}{|c|}{$\left(\right.$ Units of $\left.\mathrm{L} \mathrm{mol}^{-1} \mathrm{~s}^{-1}\right)$} & \multicolumn{2}{|c|}{ (Unitless) } \\
\hline & $k_{\mathrm{HO}}+\mathrm{C}$ & $k_{\mathrm{CO}_{3}^{--}+\mathrm{C}}$ & $k_{3} \mathrm{CDOM}^{*}+\mathrm{C}$ & $\Phi_{\mathrm{C}}$ \\
\hline $\mathrm{CLO}$ & $1.2 \times 10^{10}[39]$ & Negligible [39] & $\varphi \cdot 3.6 \times 10^{9}[73]$ & $5.5 \times 10^{-3}[39]$ \\
\hline IBP & $1.2 \times 10^{10}[36]$ & $1.2 \times 10^{6}[74]$ & $1.5 \times 10^{9}[73]$ & $0.33[36]$ \\
\hline ATZ & $3.0 \times 10^{9}[75]$ & $6.2 \times 10^{6}[76]$ & $7.2 \times 10^{8}[73]$ & $1.6 \times 10^{-2}[38]$ \\
\hline CBZ & $9.0 \times 10^{9}[77-79]$ & $4.2 \times 10^{6}[74]$ & $7.6 \times 10^{8}[37]$ & $7.8 \times 10^{-4}[37]$ \\
\hline
\end{tabular}

In the case of $\mathrm{CLO}$, the rate constant for the reaction with ${ }^{3} \mathrm{CDOM}^{*}$ took into account the back-reduction effect due to the antioxidant moieties of DOM. We used the correction factor $\varphi=(1-f)$ $+f \cdot\left[1+D O C \times\left(D O C_{1 / 2}\right)^{-1}\right]^{-1}$ (see, e.g., in $\left.[15,16]\right) . \quad D O C_{1 / 2}$ is a parameter that quantifies the back-reduction extent (the lower is $D O C_{1 / 2}$, the more important is the back reduction), whereas $f$ is the fraction of CLO that undergoes back-reduction when reacting with ${ }^{3} \mathrm{CDOM}^{*}$. The relevant values are $D_{1 / 2}=0.1 \mathrm{mg}_{\mathrm{C}} \mathrm{L}^{-1}$ and $f=0.32$ [73].

CBZ yields mutagenic acridine by both direct photolysis and reaction with $\mathrm{HO}^{\bullet}$. In particular, the acridine yields from CBZ in the two processes are, respectively, $\eta_{\text {d.p. }}=0.036$ and $\eta_{H O} \bullet=0.031$, whereas 
no acridine is formed upon reaction of $\mathrm{CBZ}$ with $\mathrm{CO}_{3}{ }^{--}$or ${ }^{3} \mathrm{CDOM}^{*}$ [37]. The overall yield of acridine from CBZ was calculated as follows [62],

$$
\eta_{\text {acridine }}=\frac{\eta_{\text {d.p. }}\left(k^{\prime} \mathrm{CBZ}\right)_{\text {d.p. }}+\eta_{\mathrm{HO}} \cdot\left(k_{\mathrm{CBZ}}^{\prime}\right)_{\mathrm{HO}} \cdot}{\left(k_{\mathrm{CBZ}}^{\prime}\right)_{\text {tot }}}
$$

where $\left(k^{\prime}{ }_{C B Z}\right)_{\text {d.p. }}$ is the first-order degradation rate constant of $\mathrm{CBZ}$ accounted for by direct photolysis, $\left(k^{\prime} \mathrm{CBZ}\right)_{\mathrm{HO}}$ the first-order $\mathrm{CBZ}$ rate constant for degradation by $\mathrm{HO}{ }^{\bullet}$, and $\left(k^{\prime} \mathrm{CBZ}\right)_{\text {tot }}$ the overall rate constant of CBZ photodegradation accounted for by all the photoinduced processes (direct photolysis, $\mathrm{HO}^{\bullet},{ }^{3} \mathrm{CDOM}^{*}$, and $\mathrm{CO}_{3}{ }^{--}$).

\section{Conclusions}

Based on data of water chemistry, we were able to produce a series of maps that describe the photochemistry of mid-latitude European rivers during the first half of the 1990s. In particular, the available data allowed us to map the steady-state $\left[{ }^{3} \mathrm{CDOM}^{*}\right]$ and $\left[\mathrm{HO}{ }^{\bullet}\right]$ as well as $\left[{ }^{1} \mathrm{O}_{2}\right]$, which is very similar to $\left[{ }^{3} \mathrm{CDOM}^{*}\right]$. The maps thus obtained allowed us to model the photodegradation kinetics of the phenylurea herbicide isoproturon, which is predicted to occur faster in Central Europe. In several French rivers, the isoproturon lifetime would be shorter than a week.

The most complete dataset was available for the Swiss rivers, which allowed us to extend the investigation to a longer time period (1990-2002). In that case, we observed limited variations in the photochemistry of $\mathrm{HO}^{\bullet}$ and ${ }^{3} \mathrm{CDOM}^{*}$, in terms of both their steady-state concentrations and the ability to degrade water pollutants. However, $\mathrm{CO}_{3}{ }^{\bullet-}$ radicals underwent a substantial decrease, which would for instance result in slower photodegradation of atrazine, as well as of other contaminants that undergo fast reaction with $\mathrm{CO}_{3}{ }^{\bullet-}$ (electron-rich phenols, amines, and sulfur-containing species).

Dataset incompleteness prevented us from extending the model to a more recent time period. For an updated European photochemical map to be produced, and possibly compared with the present data to highlight the main variations over the years, there would be the need to set-up a geographically wide database of recent water-chemistry data. They should include at least DOC, nitrate, nitrite, alkalinity, and $\mathrm{pH}$. In this way, it would be possible to get a more comprehensive view of how surface waters can naturally cope with human-induced pollution, also highlighting the most vulnerable environments from this respect.

Supplementary Materials: The following are available online, Figure S1: DOC maps for European rivers belonging to the latitude belt from 40 to $50^{\circ} \mathrm{N}$, Figure S2: Modeling the effects on the steady-state $\mathrm{HO}^{\bullet}$ concentrations of the addition of (a) nitrate, (b) nitrite and (c) bicarbonate/carbonate anions to a CDOM solution, Figure S3: Nitrate maps for European rivers belonging to the latitude belt from 40 to $50^{\circ} \mathrm{N}$, Figure S4: Time trends of the photochemical pseudo-first order degradation rate constants for pollutants in Swiss rivers, as well as acridine formation yields, Figure S5: Sun spectra reaching the earth surface in the middle of June at 40,45 and $50^{\circ} \mathrm{N}$, Table S1: European rivers and monitoring stations used for the photochemical mapping.

Author Contributions: Conceptualization, D.V.; investigation, L.C.; data curation, L.C.; writing-original draft preparation, L.C.; writing - review and editing, D.V. All authors have read and agreed to the published version of the manuscript.

Funding: The PhD fellowship of L.C. was financially supported by Compagnia di San Paolo (Torino, Italy).

Conflicts of Interest: The authors declare no conflict of interest.

\section{References}

1. Daughton, C.G.; Ternes, T.A. Pharmaceuticals and personal care products in the environment: Agents of subtle change? Environ. Health Persp. 1999, 107, 907-938. [CrossRef] [PubMed]

2. Schwarzenbach, R.P.; Escher, B.I.; Fenner, K.; Hofstetter, T.B.; Johnson, C.A.; von Gunten, U.; Wehrli, B. The challenge of micropollutants in aquatic systems. Science 2006, 313, 1072-1077. [CrossRef] [PubMed] 
3. Pal, A.; Gin, K.Y.-H.; Lin, A.Y.-C.; Reinhard, M. Impacts of emerging organic contaminants on freshwater resources: Review of recent occurrences, sources, fate and effects. Sci. Total Environ. 2010, 408, 6062-6069. [CrossRef] [PubMed]

4. Luo, Y.; Guo, W.; Ngo, H.H.; Nghiem, L.D.; Hai, F.I.; Zhang, J.; Liang, S.; Wang, X.C. A review on the occurrence of micropollutants in the aquatic environment and their fate and removal during wastewater treatment. Sci. Total Environ. 2014, 473-474, 619-641. [CrossRef] [PubMed]

5. Lindim, C.; de Zwart, D.; Cousins, I.T.; Kutsarova, S.; Kühne, R.; Schüürmann, G. Exposure and ecotoxicological risk assessment of mixtures of top prescribed pharmaceuticals in Swedish freshwaters. Chemosphere 2019, 220, 344-352. [CrossRef]

6. Riva, F.; Zuccato, E.; Davoli, E.; Fattore, E.; Castiglioni, S. Risk assessment of a mixture of emerging contaminants in surface water in a highly urbanized area in Italy. J. Hazard. Mater. 2019, 361, 103-110. [CrossRef]

7. Wang, J.; Wang, S. Removal of pharmaceuticals and personal care products (PPCPs) from wastewater: A review. J. Environ. Manag. 2016, 182, 620-640. [CrossRef]

8. Comoretto, L.; Arfib, B.; Talva, R.; Chauvelon, P.; Pichaud, M.; Chiron, S.; Höhener, P. Runoff of pesticides from rice fields in the Ile de Camargue (Rhône river delta, France): Field study and modeling. Environ. Pollut. 2008, 151, 486-493. [CrossRef]

9. Lefrancq, M.; Jadas-Hécart, A.; La Jeunesse, I.; Landry, D.; Payraudeau, S. High frequency monitoring of pesticides in runoff water to improve understanding of their transport and environmental impacts. Sci. Total Environ. 2017, 587-588, 75-86. [CrossRef]

10. Köck-Schulmeyer, M.; Ginebreda, A.; Postigo, C.; Garrido, T.; Fraile, J.; de Alda, M.L.; Barceló, D. Four-Year advanced monitoring program of polar pesticides in groundwater of Catalonia (NE-Spain). Sci. Total Environ. 2014, 470-471, 1087-1098. [CrossRef]

11. Reemtsma, T.; Berger, U.; Arp, H.P.H.; Gallard, H.; Knepper, T.P.; Neumann, M.; Quintana, J.B.; Voogt, P. Mind the gap: Persistent and mobile organic compounds - water contaminants that slip through. Environ. Sci. Technol. 2016, 50, 10308-10315. [CrossRef] [PubMed]

12. Burrows, H.D.; Canle, L.M.; Santaballa, J.A.; Steenken, S. Reaction pathways and mechanisms of photodegradation of pesticides. J. Photochem. Photobiol. B Biol. 2002, 67, 71-108. [CrossRef]

13. Remucal, C.K. The role of indirect photochemical degradation in the environmental fate of pesticides: A review. Environ. Sci. Process. Impacts 2014, 16, 628-653. [CrossRef]

14. Vione, D.; Minella, M.; Maurino, V.; Minero, C. Indirect photochemistry in sunlit surface waters: Photoinduced production of reactive transient species. Chem. Eur. J. 2014, 20, 10590-10606. [CrossRef] [PubMed]

15. Canonica, S.; Laubscher, H.U. Inhibitory effect of dissolved organic matter on triplet-Induced oxidation of aquatic contaminants. Photochem. Photobiol. Sci. 2008, 7, 547-551. [CrossRef] [PubMed]

16. Wenk, J.; Canonica, S. Phenolic antioxidants inhibit the triplet-induced transformation of anilines and sulfonamide antibiotics in aqueous solution. Environ. Sci. Technol. 2012, 46, 5455-5462. [CrossRef]

17. Trivella, A.; Stawinoga, M.; Dayan, F.E.; Cantrell, C.L.; Mazellier, P.; Richard, C. Photolysis of natural $\beta$-Triketonic herbicides in water. Water Res. 2015, 78, 28-36. [CrossRef]

18. Katagi, T. Direct photolysis mechanism of pesticides in water. J. Pestic. Sci. 2018, 43, 57-72. [CrossRef]

19. Bavcon Kralj, M.; Franko, M.; Trebše, P. Photodegradation of organophosphorus insecticides-Investigations of products and their toxicity using gas chromatography-Mass spectrometry and AChE-thermal lens spectrometric bioassay. Chemosphere 2007, 67, 99-107. [CrossRef]

20. Cermola, M.; DellaGreca, M.; Iesce, M.R.; Previtera, L.; Rubino, M.; Temussi, F.; Brigante, M. Phototransformation of fibrate drugs in aqueous media. Environ. Chem. Lett. 2005, 3, 43-47. [CrossRef]

21. Katagi, T. Aerobic microbial transformation of pesticides in surface water. J. Pestic. Sci. 2013, 38, 10-26. [CrossRef]

22. Rahm, S.; Green, N.; Norrgran, J.; Bergman, Å. Hydrolysis of environmental contaminants as an experimental tool for indication of their persistency. Environ. Sci. Technol. 2005, 39, 3128-3133. [CrossRef] [PubMed]

23. Fenner, K.; Canonica, S.; Wackett, L.P.; Elsner, M. Evaluating pesticide degradation in the environment: Blind spots and emerging opportunities. Science 2013, 341, 752. [CrossRef]

24. Al Housari, F.; Höhener, P.; Chiron, S. Factors responsible for rapid dissipation of acidic herbicides in the coastal lagoons of the Camargue (Rhône River Delta, France). Sci. Total Environ. 2011, 409, 582-587. [CrossRef] 
25. Zeng, T.; Arnold, W.A. Pesticide photolysis in prairie potholes: Probing photosensitized processes. Environ. Sci. Technol. 2013, 47, 6735-6745. [CrossRef]

26. Yassine, M.; Fuster, L.; Dévier, M.-H.; Geneste, E.; Pardon, P.; Grélard, A.; Dufourc, E.; Al Iskandarani, M.; Aït-Aïssa, S.; Garric, J.; et al. Photodegradation of novel oral anticoagulants under sunlight irradiation in aqueous matrices. Chemosphere 2018, 193, 329-336. [CrossRef]

27. Global Environment Monitoring System. Available online: www.GEMStat.org (accessed on 19 September 2018).

28. Heberer, T.; Butz, S.; Stan, H.-J. Analysis of phenoxycarboxylic acids and other acidic compounds in tap, ground, surface and sewage water at the low ng/1 level. Int. J. Environ. Anal. Chem. 1995, 58, 43-53. [CrossRef]

29. Heberer, T.; Stan, H.J. Determination of clofibric acid and N-(phenylsulfonyl)-sarcosine in sewage, river and drinking water. Int. J. Environ. Anal. Chem. 1997, 67, 113-124. [CrossRef]

30. Buser, H.-R.; Müller, M.D.; Theobald, N. Occurrence of the pharmaceutical drug clofibric acid and the herbicide mecoprop in various Swiss lakes and in the North Sea. Environ. Sci. Technol. 1998, 32, 188-192. [CrossRef]

31. Ternes, T.A. Occurrence of drugs in German sewage treatment plants and rivers. Water Res. 1998, 32, 3245-3260. [CrossRef]

32. Weigel, S.; Kuhlmann, J.; Hühnerfuss, H. Drugs and personal care products as ubiquitous pollutants: Occurrence and distribution of clofibric acid, caffeine and DEET in the North Sea. Sci. Total Environ. 2002, 295, 131-141. [CrossRef]

33. Tixier, C.; Singer, H.P.; Oellers, S.; Müller, S.R. Occurrence and fate of carbamazepine, clofibric acid, diclofenac, ibuprofen, ketoprofen, and naproxen in surface waters. Environ. Sci. Technol. 2003, 37, 1061-1068. [CrossRef] [PubMed]

34. Vogna, D.; Marotta, R.; Andreozzi, R.; Napolitano, A.; d'Ischia, M. Kinetic and chemical assessment of the $\mathrm{UV} / \mathrm{H} 2 \mathrm{O} 2$ treatment of antiepileptic drug carbamazepine. Chemosphere 2004, 54, 497-505. [CrossRef]

35. Carlos, L.; Mártire, D.O.; Gonzalez, M.C.; Gomis, J.; Bernabeu, A.; Amat, A.M.; Arques, A. Photochemical fate of a mixture of emerging pollutants in the presence of humic substances. Water Res. 2012, 46, 4732-4740. [CrossRef] [PubMed]

36. Vione, D.; Maddigapu, P.R.; De Laurentiis, E.; Minella, M.; Pazzi, M.; Maurino, V.; Minero, C.; Kouras, S.; Richard, C. Modelling the photochemical fate of ibuprofen in surface waters. Water Res. 2011, 45, 6725-6736. [CrossRef]

37. De Laurentiis, E.; Chiron, S.; Kouras-Hadef, S.; Richard, C.; Minella, M.; Maurino, V.; Minero, C.; Vione, D. Photochemical fate of carbamazepine in surface freshwaters: Laboratory measures and modeling. Environ. Sci. Technol. 2012, 46, 8164-8173. [CrossRef]

38. Marchetti, G.; Minella, M.; Maurino, V.; Minero, C.; Vione, D. Photochemical transformation of atrazine and formation of photointermediates under conditions relevant to sunlit surface waters: Laboratory measures and modelling. Water Res. 2013, 47, 6211-6222. [CrossRef]

39. Avetta, P.; Fabbri, D.; Minella, M.; Brigante, M.; Maurino, V.; Minero, C.; Pazzi, M.; Vione, V. Assessing the phototransformation of diclofenac, clofibric acid and naproxen in surface waters: Model predictions and comparison with field data. Water Res. 2016, 105, 383-394. [CrossRef]

40. McNeill, K.; Canonica, S. Triplet state dissolved organic matter in aquatic photochemistry: Reaction mechanisms, substrate scope, and photophysical properties. Environ. Sci.-Proc. Impacts 2016, 18, 1381-1399. [CrossRef]

41. Grebel, J.E.; Pignatello, J.J.; William, A.; Mitch, W.A. Sorbic acid as a quantitative probe for the formation, scavenging and steady-state concentrations of the triplet-excited state of organic compounds. Water Res. 2011, 45, 6535-6544. [CrossRef]

42. QGIS Developmental Team. QGIS Geographic Information System. In Open Source Geospatial Foundation Project; Available online: https://www.osgeo.org (accessed on 3 July 2019).

43. Buxton, G.V.; Greenstock, C.L.; Helman, W.P.; Ross, A.B. Critical review of rate constants for reactions of hydrated electrons, hydrogen atoms and hydroxyl radicals $\left(\bullet^{\bullet} \mathrm{OH} / \mathrm{O}^{-\bullet}\right)$ in aqueous solution. J. Phys. Chem. Ref. Data 1988, 17, 513-886. [CrossRef]

44. Mack, J.; Bolton, J.R. Photochemistry of nitrite and nitrate in aqueous solution: A review. J. Photochem. Photobiol. A 1999, 128, 1-13. [CrossRef] 
45. Canonica, S.; Kohn, T.; Mac, M.; Real, F.J.; Wirz, J.; von Gunten, U. Photosensitizer method to determine rate constants for the reaction of carbonate radical with organic compounds. Environ. Sci. Technol. 2005, 39, 9182-9188. [CrossRef] [PubMed]

46. Yan, S.; Liu, Y.; Lian, L.; Li, R.; Ma, J.; Zhou, H.; Song, W. Photochemical formation of carbonate radical and its reaction with dissolved organic matters. Water Res. 2019, 161, 288-296. [CrossRef] [PubMed]

47. Huang, J.; Mabury, S.A. A new method for measuring carbonate radical reactivity toward pesticides. Enviorn. Toxicol. Chem. 2000, 19, 1501-1507. [CrossRef]

48. Gerecke, A.C.; Canonica, S.; Muller, S.R.; Scharer, M.; Schwarzenbach, R.P. Quantification of dissolved natural organic matter (DOM) mediated phototransformation of phenylurea herbicides in lakes. Environ. Sci. Technol. 2001, 35, 3915-3923. [CrossRef]

49. Canonica, S.; Hellrung, B.; Müller, P.; Wirz, J. Aqueous oxidation of phenyluera herbicides by triplet aromatic ketones. Environ. Sci. Technol. 2006, 40, 6636-6641. [CrossRef]

50. Benitez, F.J.; Real, F.J.; Acero, J.L.; Garcia, C. Kinetics of the transformation of phenylurea herbicides during ozonation of natural waters: Rate constants and model predictions. Water Res. 2007, 41, 4073-4084. [CrossRef]

51. Beck, A.J.; Lam, V.; Henderson, D.E.; Beven, K.J.; Harris, G.L.; Howse, K.R.; Johnny Johnston, A.E.; Jones, K.C. Movement of water and the herbicides atrazine and isoproturon through a large structured clay soil core. J. Contam. Hydrol. 1995, 19, 237-260. [CrossRef]

52. Williams, R.J.; Brooke, D.N.; Matthiessen, P.; Mills, M.; Turnbull, A.; Harrison, R.M. Pesticide transport to surface waters within an agricultural catchment. J. Inst. Water Environ. Manag. 1995, 9, 72-81. [CrossRef]

53. Klöppel, H.; Haider, J.; Kördel, W. Herbicides in surface runoff: A rainfall simulation study on small plots in the field. Chemosphere 1994, 28, 649-662. [CrossRef]

54. Pichon, V.; Chen, L.; Hennion, M.-C. On-Line preconcentration and liquid chromatographic analysis of phenylurea pesticides in environmental water using a silica-based immunosorbent. Anal. Chim. Acta 1995, 311, 429-436. [CrossRef]

55. Schuelein, J.; Glaessgen, W.E.; Hertkorn, N.; Schroeder, P.; Sandermann, H., Jr.; Kettrup, A. Detection and identification of the herbicide isoproturon and its metabolites in field samples after a heavy rainfall event. Int. J. Environ. Anal. Chem. 1996, 65, 193-202. [CrossRef]

56. Stangroom, S.J.; Collins, C.D.; Lester, J.N. Sources of organic micropollutants to lowland rivers. Environ. Technol. 1998, 19, 643-666. [CrossRef]

57. Fingler, S.; Mendaš, G.; Dvoršćak, M.; Stipičević, S.; Vasilić, Ž.; Drevenkar, V. Herbicide micropollutants in surface, ground and drinking waters within and near the area of Zagreb, Croatia. Environ. Sci. Pollut. Res. 2017, 24, 11017-11030. [CrossRef]

58. Barbosa, M.O.; Ribeiro, A.R.; Ratola, N.; Hain, E.; Homem, V.; Pereira, M.F.R.; Blaney, L.; Silva, A.M.T. Spatial and seasonal occurrence of micropollutants in four Portuguese rivers and a case study for fluorescence excitation-emission matrices. Sci. Total Environ. 2018, 644, 1128-1140. [CrossRef]

59. Quintana, J.; de la Cal, A.; Boleda, M.R. Monitoring the complex occurrence of pesticides in the Llobregat basin, natural and drinking waters in Barcelona metropolitan area (Catalonia, NE Spain) by a validated multi-residue online analytical method. Sci. Total Environ. 2019, 692, 952-965. [CrossRef]

60. Knauert, S.; Escher, B.; Singer, H.; Hollender, J.; Knauer, K. Mixture toxicity of three photosystem II inhibitors (atrazine, isoproturon, and diuron) toward photosynthesis of freshwater phytoplankton studied in outdoor mesocosms. Environ. Sci. Technol. 2008, 42, 6424-6430. [CrossRef]

61. Sigurnjak, M.; Ukić, Š.; Cvetnić, M.; Markić, M.; Stankov, M.N.; Rasulev, B.; Kušić, H.; Božić, A.L.; Rogošić, M.; Bolanča, T. Combined toxicities of binary mixtures of alachlor, chlorfenvinphos, diuron and isoproturon. Chemosphere 2020, 240, 124973. [CrossRef]

62. Bodrato, M.; Vione, D. APEX (Aqueous Photochemistry of Environmentally occurring Xenobiotics): A free software tool to predict the kinetics of photochemical processes in surface waters. Environ. Sci. Proc. Imp. 2014, 16, 732-740. [CrossRef]

63. Shchevyev, Y.L.; Bogoyavlensky, N.Y. Calculation of the average flow velocity in rivers. The hydrological basis for water resources management. In Proceedings of the Beijing Symposium on the Hydrological Basis for Water Resources Management, Beijing, China, 23-26 October 1990; IAHS Publ. no. 197. International Association of Hydrological Sciences: Wallingford, UK, 1990; pp. 89-91.

64. Schulze, K.; Hunger, M.; Döll, P. Simulating river flow velocity on global scale. Adv. Geosci. 2005, 5, $133-136$. [CrossRef] 
65. Vione, D.; Scozzaro, A. Photochemistry of surface fresh waters in the framework of climate change. Environ. Sci. Technol. 2019, 53, 7945-7963. [CrossRef] [PubMed]

66. Worrall, F.; Howden, N.J.K.; Burt, T.P. A method of estimating in-stream residence time of water in rivers. J. Hydrol. 2014, 512, 274-284. [CrossRef]

67. Carena, L.; Terrenzio, D.; Mosley, L.M.; Toldo, M.; Minella, M.; Vione, D. Photochemical consequences of prolonged hydrological drought: A model assessment of the Lower Lakes of the Murray-Darling Basin (Southern Australia). Chemosphere 2019, 236, 124356. [CrossRef]

68. National Center for Atmospheric Research (NCAR). 2015. Quick TUV Calculator [WWW Document]. Available online: http://cprm.acom.ucar.edu/Models/TUV/Interactive_TUV/ (accessed on 15 July 2019).

69. Chang, E.E.; Chiang, P.C.; Lin, T.F. Development of surrogate organic contaminant parameters for source water quality standards in Taiwan, ROC. Chemosphere 1998, 37, 593-606. [CrossRef]

70. Minella, M.; De Laurentiis, E.; Buhvestova, O.; Haldna, M.; Kangur, K.; Maurino, V.; Minero, C.; Vione, D. Modelling lake-water photochemistry: Three-Decade assessment of the steady-state concentration of photoreactive transients $\left(\mathrm{OH}, \mathrm{CO}_{3}{ }^{-}\right.$and $\left.3 \mathrm{CDOM}^{*}\right)$ in the surface water of polymictic Lake Peipsi (Estonia/Russia). Chemosphere 2013, 90, 2589-2596. [CrossRef]

71. Clark, J.B.; Neale, P.; Tzortziou, M.; Cao, F.; Hood, R.R. A mechanistic model of photochemical transformation and degradation of colored dissolved organic matter. Mar. Chem. 2019, 214, 103666. [CrossRef]

72. Marchisio, A.; Minella, M.; Maurino, V.; Minero, C.; Vione, D. Photogeneration of reactive transient species upon irradiation of natural water samples: Formation quantum yields in different spectral intervals, and implications for the photochemistry of surface waters. Water Res. 2015, 73, 145-156. [CrossRef]

73. Carena, L.; Puscasu, C.G.; Comis, S.; Sarakha, M.; Vione, D. Environmental photodegradation of emerging contaminants: A re-Examination of the importance of triplet-sensitised processes, based on the use of 4-carboxybenzophenone as proxy for the chromophoric dissolved organic matter. Chemosphere 2019, 237, 124476. [CrossRef]

74. Huang, Y.; Kong, M.; Westerman, D.; Xu, E.G.; Coffin, S.; Cochran, K.H.; Liu, Y.; Richardson, S.D.; Schlenk, D.; Dionysiou, D.D. Effects of $\mathrm{HCO}_{3}{ }^{-}$on degradation of toxic contaminants of emerging concern by $\mathrm{UV} / \mathrm{NO}_{3}{ }^{-}$. Environ. Sci. Technol. 2018, 52, 12697-12707. [CrossRef]

75. Acero, J.L.; Stemmler, K.; von Gunten, U. Degradation kinetics of atrazine and its degradation products with ozone and $\mathrm{OH}$ radicals: A predictive tool for drinking water treatment. Environ. Sci. Technol. 2000, 34, 591-597. [CrossRef]

76. Larson, R.A.; Zepp, R.G. Reactivity of the carbonate radical with aniline derivatives. Environ. Toxicol. Chem. 1988, 7, 265-274. [CrossRef]

77. Huber, M.M.; Canonica, S.; Park, G.-Y.; von Gunten, U. Oxidation of pharmaceuticals during ozonation and advanced oxidation processes. Environ. Sci. Technol. 2003, 37, 1016-1024. [CrossRef] [PubMed]

78. Lam, M.W.; Mabury, S.A. Photodegradation of the pharmaceuticals atorvastatin, carbamazepine, levofloxacin, and sulfamethoxazole in natural waters. Aquat. Sci. 2005, 67, 177-188. [CrossRef]

79. Hora, P.I.; Novak, P.J.; Arnold, W.A. Photodegradation of pharmaceutical compounds in partially nitritated wastewater during UV irradiation. Environ. Sci. Water Res. Technol. 2019, 5, 897. [CrossRef]

Sample Availability: no real samples were used in this modeling study.

(C) 2020 by the authors. Licensee MDPI, Basel, Switzerland. This article is an open access article distributed under the terms and conditions of the Creative Commons Attribution (CC BY) license (http://creativecommons.org/licenses/by/4.0/). 